\title{
TEN GOOD PRACTICES IN ENVIRONMENTAL CONSTITUTIONALISM: STRUCTURE, TEXT AND JUSTICIABILITY ${ }^{1}$
}

James R. May ${ }^{2}$

Erin Daly ${ }^{3}$

\begin{abstract}
Environmental constitutionalism is a relatively recent phenomenon at the confluence of constitutional law, international law, human rights, and environmental law. It embodies the recognition that the environment is a proper subject for protection in constitutional texts and for vindication by constitutional courts worldwide. This chapter posits ten "good practices" - those attributes that make effective outcomes more likely, but not assured - in environmental constitutionalism for advancing positive environmental outcomes considering energy, and governance and sustainability. Good practices in environmental constitutionalism can serve as a useful construct for considering the relationship between sustainability, energy and governance. Accordingly, Section A examines the ten practices that are consequential for effectuating environmental constitutionalism and positive environmental outcomes. Section B then explains how the Robinson Township decision out of the Commonwealth of Pennsylvania in the United States provides a recent example just how good practices can have a positive impact on environmental outcomes in practice.
\end{abstract}

Keywords: Environmental constitutionalism. Environmental outcomes. Justiciability

\section{INTRODUCTION}

Environmental constitutionalism is a relatively recent phenomenon at the confluence of constitutional law, international law, human rights, and environmental law. It embodies the recognition that the environment is a proper subject for protection in the constitutional texts and for vindication by constitutional courts worldwide. ${ }^{4}$ This chapter posits ten "good practices" - those attributes

1 This article was published in the e-book: O Estado no mundo globalizado: soberania, transnacionalidade e sustentabilidade. Org. CRUZ, Paulo Márcio; GARCIA, Heloise Siqueira; GUASQUE, Bárbara. Available at: http://emeron.tjro.jus.br/capa/952-emeron-lanca-primeiro-e-book-com-artigos-de-magistrados-rondonienses.

2 Professor of Law at Widener University

3 Interim Dean and Professor of Law at Widener University.

4 See generally: MAY, James R.; DALY, Erin. 'Global Constitutional Environmental Rights.' In: ALAM, Shawkat; BHUIYAN, Jahid Hossain; CHOWDHURY, Tareq M.R.; TECHERA, Erika

J. Routledge Handbook of International Environmental Law. Routledge, 2012; MAY, James R.; DALY, Erin. 'Vindicating Fundamental Environmental Rights Worldwide.' Ore. Rev. Intl. L. v. 11, p. 365-440, 2010; MAY, James R.; DALY, Erin. 'New Directors in Earth Rights, Environmental Rights and Human Rights: Six Facets of Constitutionally Embedded Environmental Rights Worldwide.' IUCN Academy of Environmental Law E-Journal. v. 1, 2011; MAY, James R.; DALY, Erin. 'Constitutional Environmental Rights Worldwide.' In: 
that make effective outcomes more likely, but not assured - in environmental constitutionalism for advancing positive environmental outcomes considering energy, governance and sustainability.

Good practices in environmental constitutionalism can serve as a useful construct when considering the relationship between sustainability, energy and governance. Accordingly, Section A examines ten practices that are consequential for effectuating environmental constitutionalism and positive environmental outcomes. Section B goes on to explain how the Robinson Township decision out of the Commonwealth of Pennsylvania in the United States provides a recent example of how good practices can have a positive impact on environmental outcomes.

\section{TEN GOOD PRACTICES IN ENVIRONMENTAL CONSTITUTIONALISM}

Thefollowing section liststen'good practices'inenvironmental constitutionalism. However, we do not wish to imply that adherence to any particular approach or combination of practices will guarantee a particular outcome, including the effective deployment of environmental constitutionalism. In fact, any attempt to identify good practices must involve a tincture of magical thinking, and is certain to invite, at least, healthy criticism. The rest approximates a sort of social scientific method involving hypothesis, experiment, and reflection. The same caveat applies to our assignations - we merely suggest that bearing in mind these ten correlative but non-causative considerations will increase the likelihood of positive environmental outcomes.

\section{SITUATE ENVIRONMENTAL CONSTITUTIONALISM IN AMENABLE SYSTEMS, I.E. THOSE AMENABLE TO SOCIAL, ECONOMIC AND CULTURAL RIGHTS, AND THOSE WITH CIVIL LAW TRADITIONS}

The first good practice in environmental constitutionalism is finding a suitable fit, i.e. a constitutional and governance structure that is amenable to environmental 
constitutionalism. Countries that demonstrate a constitutional commitment to social, economic, and cultural rights (SECS) appear to be those that are more amenable to environmental constitutionalism. SECs are designed to protect human well-being and quality of life, aiming to foster minimum standards of, or access to economic and social well-being. They include the rights to work, to form or join a trade union, and to go on strike, and the guarantee of social security, child protection, food and housing, healthcare, and education. Because rights to a quality sustainable environment, whether land or water, have social, economic and cultural implications, they are more likely to be found in constitutions that recognize other SEC rights. ${ }^{5}$

A recent sweeping report from the Toronto Initiative for Economic and Social Rights (TIESR) dataset supports the observation that national acceptance of SECS correlates with good practices in environmental constitutionalism. The TIESR study measured the presence, absence, and justiciability of seventeen SECs ${ }^{6}$ that include a right to a healthy environment among constitutions worldwide. ${ }^{7}$ Importantly, the TIESR study shows a strong correlation between SECs in general and environmental rights in particular. It shows that countries with multiple SECs are more apt to enshrine a right to a quality environment. The TIESR study concludes that 73 countries (or about 53.7 percent of the survey field) of those countries with SECs also constitutionally enshrine a right to a quality environment. ${ }^{8}$

Moreover, Gellers concludes that external regulatory influences tend to have the most profound effect on a country's predilection toward recognizing social and economic rights, including environmental rights. ${ }^{9}$ Indeed, the external normative pressures may be culturally, historically, and geographically contingent: the common values shared by many Latin American countries - many

5 JUNG, Courtney; ROSEVEAR, Evan. Economic and Social Rights Across Time, Regions, and Legal Traditions: A Preliminary Analysis of the TIESR Dataset. 30 Nordic Jrnl. Hum. Rights, 2012, p. 372; 376.

6 The TIESR report refers to these as "Economic and Social Rights," or "ESRs."

7 The TIESR dataset is available online at http://www.tiesr.org.

8 JUNG, Courtney; ROSEVEAR, Evan. Economic and Social Rights Across Time, Regions, and Legal Traditions: A Preliminary Analysis of the TIESR Dataset. 30 Nordic Jrnl. Hum. Rights, 2012, p. 381.

9 GELLERS, Joshua. Survival of the Greenest: A Statistical Analysis of Constitutional Environmental Rights, 2012. Available at: <http://papers.ssrn.com/sol3/papers. cfm?abstract_ id $=2103960>$ 
of which are committed to a deep form of environmental constitutionalism - may be distinct from those shared by middle eastern countries, or Asian countries, thus accounting for regional differences in approaches to constitutionalism and environmentalism.

Moreover, environmental constitutionalism tends to enjoy more success in constitutional systems grounded in civil law traditions than in those that operate under other legal traditions. This is significant, considering that governance structures worldwide predominantly reflect civil law traditions. ${ }^{10}$ Common law systems are less likely to embody environmental constitutionalism, although more likely than Muslim or customary law-based systems, which are least likely to reflect environmental constitutionalism. ${ }^{11}$

\section{CLEARLY ARTICULATE A POSITIVE INDIVIDUAL OR COLLECTIVE RIGHT, SUCH AS “EVERYONE HAS AN ENFORCEABLE RIGHT TO A QUALITY ENVIRONMENT."}

Textually, the simplest good practice in environmental constitutionalism is to guarantee individuated (or collective) environmental rights clearly and directly, such as by recognizing a 'that everyone' has the right to an 'adequate,' 'clean,' 'healthy,' 'productive,' 'harmonious,' or 'sustainable' environment.

Where the constitution is not explicit on the question of environmental protection, the courts in some countries - particularly India and its neighbors ${ }^{12}$ have inferred this protection from other constitutional rights, such as the right to life, health, or dignity. ${ }^{13}$ While these innovations are welcome from the standpoint

10 The TIESR study distinguished constitutions as follows: Civil Law, $\mathrm{n}=112$ Common Law, $\mathrm{n}=35$ Customary Law, $\mathrm{n}=57$ Muslim Law, $\mathrm{n}=34$. JUNG, Courtney; ROSEVEAR, Evan. Economic and Social Rights Across Time, Regions, and Legal Traditions: A Preliminary Analysis of the TIESR Dataset. 30 Nordic Jrnl. Hum. Rights, 2012, p. 388.

11 JUNG, Courtney; ROSEVEAR, Evan. Economic and Social Rights Across Time, Regions, and Legal Traditions: A Preliminary Analysis of the TIESR Dataset. 30 Nordic Jrnl. Hum. Rights, 2012, p. 394.

12 JUNG, Courtney; ROSEVEAR, Evan. Economic and Social Rights Across Time, Regions, and Legal Traditions: A Preliminary Analysis of the TIESR Dataset. 30 Nordic Jrnl. Hum. Rights, 2012, p. 167-70. See generally, SRIPATI, Vijayashri. Human Rights in India Fifty Years after Independence. 26 Denv. J. Int'I L. \& Pol'y, 1997, p. 93-100.

13 BRUCH, Carl; COKER, Wole; VANARSDALE, Chris. 'Constitutional Environmental Law: Giving Force to Fundamental Principles in Africa.' Colum. J. Envtl. L, v. 26, p. 166-176, 2001 
of environmental protection, they may not be as durable as judicial vindication of clear constitutional mandates: in environmental constitutionalism, as elsewhere, the more grounded in constitutional text the judicial consecration is, the less susceptible it will be to criticism, repudiation, or reversal.

A related good practice is to provide constitutional history, which can assist with interpretive questions. Environmental provisions are often enacted with little if any guidance on threshold questions. Except for some exceptions, there is little evidence of the intent of those drafting these provisions that would provide guidance to their interpreters. ${ }^{14} \mathrm{~A}$ good practice, which is seen far more often as a breach, is to include some explanation or interpretive guidance about the environmental provisions in the constitutional drafting history. Where this is done, - as it was in the adoption of the provision for the rights of nature in Ecuador - it can be of great usefulness and persuasive authority for a court seeking to interpret the constitutional text. ${ }^{15}$

\section{MAKE PROVISIONS SELF-EXECUTING BY ADDING THEM TO “BILL” OR “DECLARATION” OF RIGHTS, PLACING THEM ON PAR WITH TRADITIONAL FIRST-ORDER RIGHTS}

The most effective substantive environmental rights are those that are selfexecuting. Self-executing provisions may be enforced without the need for interceding legislative action. Indeed, the whole point of entrenching a right is to ensure that the value remains protected even if (and especially when) it is not supported by a political majority.

Self-execution of environmental rights can be exhibited either structurally or syntactically. Substantive environmental rights provisions that appear (discussing constitutional interpretation in Tanzania, India, Pakistan, Bangladesh, Nepal, Columbia, Ecuador, Costa Rica, and some countries in Africa).

14 The lower court in the Ecuadorian rights of nature case constitutes one exception, as it quotes at length from the speech of Alberto Acosta, President of the Constituent Assembly, to understand more fully the purpose of constitutionalizing the rights of nature. See WHEELER c. Director de la Procuraduria General Del Estado de Loja Juicio, No. 11121-20110010 ('Wheeler'). Available at <http://blogs.law.widener.edu/envirolawblog/2011/07/12/ ecuadorian-courtrecognizes-constitutional-right-to-nature/>.

15 Wheeler, quoting the chair of the constitutional drafting commission Acosta on the importance of the rights of nature. 
structurally in a constitution alongside first-generation constitutional rights are those most likely to be self-executing. ${ }^{16}$ Some nations place substantive environmental rights among other first-generation civil and political rights by designating them as an express "Right," or "Major," "Human," "Fundamental," "Basic," or "Guaranteed" right.

The constitutions of the majority of nations that have adopted substantive environmental rights seem to classify them as self-executing rights. Such structural placement increases the likelihood that such provisions will be selfexecuting and enforceable.

Structural placement or syntax can also suggest that some substantive environmental rights provisions may not be self-executing and enforceable. Moreover, placing substantive environmental rights within preambles, among general provisions, or in statements of general policy may suggest something other than a self-executing right. On the other hand, when the Pennsylvania Supreme Court finally took the constitutional environmental right of that right seriously, it noted that the placement of the provision within the Declaration of Rights of the Pennsylvania Constitution gives the rights protected therein the same degree of protection as any other individual right: "The right delineated in the first clause of Section 27 presumptively is on par with, and enforceable to the same extent as, any other right reserved to the people in Article I. See PA. CONST. art. I, § 25 ("everything" in Article I is excepted from government's general powers and is to remain inviolate)." ${ }^{17}$

Anything the constitution drafters can do to reinforce the importance, if not the primacy, of constitutional rights will promote their efficacy. Some constitutions allow the government to elevate environmental values over others. Some allow the government to restrict private property rights in favor of environmental policies, for example, that of Mongolia, which includes the wording: "The State shall have the right to ... confiscate the land if it is used in a manner adverse to the health of the population, the interests of environmental protection and national security". Chile's constitution even contains a 'trump' card over all other rights in favor of 16 See Hayward, supra note 3, at 93-128 (examining challenges of judicial enforcement of fundamental environmental rights); Bruckerhoff, supra note 35, at 627-28 (footnotes omitted)).

17 Robinson Township v. Commonwealth of Pennsylvania (Pa. 2013) at 78. 
the environment: "The law can establish specific restrictions on the exercise of certain rights or freedoms in order to protect the environment."

\section{ALIGN ENVIRONMENTAL CONSTITUTIONALISM}

Substantive environmental rights provisions can be made even stronger when they are supported by allied substantive rights, including rights to water. Another good practice relating to textual instantiation of environmental values is that the more detailed the provision, the better. Many constitutions contain elaborate articulations of the rights, values, processes, and justifications for environmental protections. South Africa's environmental provision (from 1996) embraces both an individual right and a set of directive principles aimed at preventing pollution, promoting conservation, and securing sustainable development. Argentina's 1994 constitution protects the interests of present and future generations, and requires that the government repair environmental damage, use natural resources "rational[ly]," preserve Argentina's natural and cultural heritage and biological diversity, and require environmental information and education. ${ }^{18}$ Likewise, France's constitution requires environmental education and training ("Education and training on the environment shall contribute to the exercise of the rights and obligations defined by this Charter").

Some environmental provisions specifically address certain types of activities that may be especially harmful to the local environment. For example, several countries prohibit the disposal of nuclear or hazardous waste or substances that are imported from another country, including Niger ("The transit, importation, storage, landfill, [and] dumping on the national territory of foreign pollutants or toxic wastes, as well as any agreement relating [to it] constitute a crime against the Nation, punishable by the law").

Some constitutions identify governmental responsibilities toward specific objects of the environment, including the climate. The Dominican Republic's 18 ARGENTINA. Argentina Constitution. 1994, Art. 42. 
constitution, for example, provides that: "The formulation and execution, through the law, of a plan of territorial ordering that assures the efficient and sustainable use of the natural resources or the Nation, in accordance with the need of adaption to climate change, is [a] priority of the State."

The constitutions of other countries expressly restrain or restrict energyrelated activities that could adversely affect the environment, including that of Ecuador ("The State shall promote, in the public and private sectors, the use of environmentally clean technologies and nonpolluting and low-impact alternative sources of energy. Energy sovereignty shall not be achieved to the detriment of food sovereignty nor shall it affect the right to water").

Addressing rights to water is another common good practice. Indeed, about 30 constitutions provide for rights to water as a human or environmental right, including at least one dozen countries that instantiate a human right to a fair distribution of clean, safe, or potable water. ${ }^{19}$ For example, South Africa's constitution makes a strong commitment to acknowledging water as a fundamental human right by asserting an enforceable individual right to access to drinking water. ${ }^{20}$

Ecuador's protection for the rights of nature ${ }^{21}$ is another example of the alliance between substantive environmental rights and other constitutional guarantees whose combined effect is to strengthen the hands of the courts when they attempt to vindicate environmental rights. The Ecuadorian provision further confirms that this right is not merely hortatory in that it empowers each "person, community, people, or nationality" ${ }^{\prime 22}$ to exercise public authority to enforce the right, according to normal constitutional processes. ${ }^{23}$

19 These are: Bolivia (Art. 16(I)), Colombia (Art. 366), the Democratic Republic of Congo (Art. 48), Ecuador (Art. 12), Ethiopia (Art. 90(1)), Gambia (Art. 216(4)), the Maldives (Art. 23), Panama (Arts. 110 and 118), Swaziland (Art. 215), Switzerland (Art. 76), Uganda (Arts. XIV(b) and XXI), Uruguay (Art. 47), Venezuela (Arts. 127 and 304), and Zambia (Art. $112(d))$. See Boyd, supra note 4, at 85.

20 South Africa Const., ch. 2, art. 27 (1)(b): 'Everyone has the right to have access to- (b) sufficient food and water...'

21 Constitucion Politica de la Republica del Ecuador, title II, ch. 7, art. 71 and arts. 72-74.

22 Constitucion Politica de la Republica del Ecuador, title II, ch. 7, art. 71.

23 Constitucion Politica de la Republica del Ecuador, title II, ch. 7, art. 71. 


\section{RECOGNIZE EMERGING AREAS OF ENVIRONMENTAL CONSTITUTIONALISM INCLUDING SUSTAINABILITY, PUBLIC TRUST, CLIMATE, AND BIOCENTRISM}

Another good practice is to reflect emerging areas in environmental constitutionalism, including sustainability, rights of nature, public trust, and climate change.

\section{DEPLOY SUSTAINABILITY}

Environmental sustainability is an amorphous concept that stands for the proposition that present generations should use resources in order to preserve opportunities for future generations. Nearly twenty countries expressly recognize a constitutional goal of 'sustainability' or 'sustainable development', although most of these are in sections of the constitutions, or written in language that indicates that they are not amenable to judicial enforcement. For example, Switzerland's constitution contains a specific section entitled "Sustainable Development," which provides that "The Confederation and the Cantons shall endeavor to achieve a balanced and sustainable relationship between nature and its capacity to renew itself and the demands placed on it by the population."

Sustainability recognizes responsibilities owed to those who follow. The constitutions of about a dozen countries give at least a passing nod to 'future generations.' For example, Papua New Guinea's constitution requires the state to hold environmental resources "in trust for future generations" and "for the benefit of future generations."

The strongest embodiment of environmental sustainability would seem to stem from those constitutions that promote sustainable development for the purpose of protecting the interests of future generations. The constitutions of about a dozen countries contain this sort of hybrid pronouncement. For example, Mozambique's constitution requires that the state, "[w]ith a view to guaranteeing 
the right to the environment within the framework of sustainable development ... shall adopt policies aimed at ... guaranteeing the rational utilisation of natural resources and the safeguarding of their capacity to regenerate, ecological stability and the rights of future generations."

The constitutions of some countries require that specific resources be developed with future generations in mind. For example, the Dominican Republic provides that "nonrenewable natural resources can only be explored and exploited by individuals under sustainable environmental criteria ..." and provides for the protection of the environment "for the benefit of the present and future generations.."

\section{PUBLIC TRUST}

Environmental constitutionalism often reflects notions of public trust. The constitutions of about half a dozen countries reference holding or protecting resources for the 'public trust' or some variation of that terminology. These tend to impose a trust responsibility upon policy makers, rulers, or citizens to hold resources in trust for current or future generations. Some specify trust responsibilities as a general governing norm. For example, the Ugandan Constitution provides that "the Government or a local government, as determined by Parliament by law, shall hold in trust for the people and protect, natural lakes, rivers, wetlands, forest reserves, game reserves, national parks and any land to be reserved for ecological and touristic purposes for the common good of all citizens." Reflecting traditional views of sovereignty, some constitutions invest public trust in a supreme leader. For example, Ghana's constitution provides that "All public lands in Ghana shall be vested in the President on behalf of, and in trust for, the people of Ghana," and "every mineral in its natural state in, under or upon any land in Ghana, rivers, streams, water courses throughout Ghana, the exclusive economic zone and any area covered by the territorial sea or continental shelf is the property of the Republic of Ghana and shall be vested in the President on behalf of, and in trust for the people of Ghana." 
Some constitutional provisions hold citizens accountable to hold resources in trust for future generations. For example, Tanzania's constitution provides "that all citizens together possess all the natural resources of the country in trust for their descendants."

\section{CLIMATE CHANGE}

Shortcomings in international and domestic responses to climate change create opportunities for tactical deployment of environmental constitutionalism. Thus far, however, very few countries have seen fit to address climate change constitutionally. The Dominican Republic's constitution is explicit on the point, with a provision under "The Organization of the Territory" that provides for a "plan of territorial ordering that assures the efficient and sustainable use of the natural resources of the Nation, in accordance with the need for adaptation to climate change ..."

Environmental constitutionalism might play an important, albeit limited role in local approaches to climate change. Constitutions can, for one thing, direct governments to enact and implement policies to address the effects of climate change in ways not accomplished through existing international and national laws. And once these polices have been absorbed into the constitutional texts, the courts can force action by enforcing these provisions, even if this is accomplished gradually.

BIOCENTRIC RIGHTS

Environmental constitutionalism advancing the right of nature is emergent and insistent, but still uncommon. The constitutionalization of the rights of nature is part of a growing global movement, highlighting the importance of the natural environment for its own sake and as a whole, rather than as an aggregation of resources to be harnessed by humans for various purposes. ${ }^{24}$

24 DALY, Erin. "The Ecuadorian Exemplar: The First Ever Vindications Of Constitutional Rights Of Nature." RECIEL 21 (1) 2012. Available at: <http://celdf.live2.radicaldesigns.org/downloads/The_Ecuadorian_ Exemplar_The_First_Ever_Vindications_of_Constitutional_Rights_of_Nature.pdf>.; Global 
Environmental constitutionalism addressing nature appears as either governmental duties or substantive rights of nature. First, the constitutions of some countries require all branches of government to protect nature. Germany's constitution, for instance, requires that the government protect "the natural bases of life and the animals within the framework of the constitutional order by legislation, and in accordance with law and justice, by executive and judicial power."

Secondly, biocentric environmental constitutionalism - recognizing the right of nature - has been pushed most emphatically by two countries in South America. In 2008, Ecuador amended its constitution to recognize the right of nature, providing that: "Nature, or Pachamama, where life is reproduced and created, has the right to integral respect for her existence, her maintenance, and for the regeneration of her vital cycles, structure, functions, and evolutionary processes." ${ }^{25}$ Bolivia also has a framework law recognizing the rights of nature, ${ }^{26}$ and discussions of constitutional reforms to recognize them have taken place in Turkey. ${ }^{27}$ Moreover, rights of nature have recently found traction at the supersubnational level, including in various municipalities in the United States. ${ }^{28}$

Even without explicit protection for the rights of nature, courts might be encouraged to interpret constitutional environmental provisions as protecting natural resources, the natural environment, or the biodiversity within it. For instance, in vindicating the Chilean constitution's right to a healthy environment, the Chilean Constitutional Court held that the right extended to cases involving environmental degradation per se, regardless of its effect on humans. This would

Alliance for the Rights of Nature. rightsofnature.org; Community Environmental Legal Defense Fund. http://www.celdf.org/rights-of-nature.

25 Constitución Política de la República del Ecuador. title II, ch. seven, arts. 71-74. For an additional review of the judicial progressiveness in securing environmental rights in Ecuador, see Radden Patrick Keefe. "Reversal of Fortune; A crusading lawyer helped Ecuadorans secure a huge environmental judgment against Chevron. But did he go too far?," The New Yorker, January 9, 2012.

26 See VIDAL, John. Bolivia enshrines natural world's rights with equal status for Mother Earth. Avaiable at: <http://www.guardian.co.uk/environment/2011/apr/10/bolivia-enshrines-natural-worlds-rights>.

27 See GLOBAL ALLIANCE FOR THE RIGHTS OF NATURE. Turkey calling for ecological constitution. Avaiable at: <http://therightsofnature.org/rights-of-nature-laws/turkey-ecological-constitution/>.

28 The Community Legal Defense Fund. http://www.celdf.org/-1-27. 
include cases requiring the clean-up of beaches of Chañaral, Chile, for instance, where copper tailing wastes had been deposited for 50 years, destroying the marine life. ${ }^{29}$ Where this is the norm, the case would center on whether the environment itself is healthy, not on whether the environmental degradation induced any harm to human beings. This is especially important with respect to water-related rights, where ecological concerns may be inconsistent with the human right to adequate water for personal and commercial uses.

\section{SCAFFOLD ADDITIONAL STATUTORY AND REGULATORY MEANS TO IMPLEMENT CONSTITUTIONAL PREROGATIVES}

The impact of constitutional provisions, whether elaborate or sparse, can also be enhanced by extra-constitutional scaffolding. In the Philippines and Argentina, elaborate statutory schemes promote and facilitate vindication of environmental constitutional rights. In the Philippines, the Supreme Court has developed a set of "Rules Of Procedure For Environmental Cases" that encourage the vindication of constitutional and other environmental rights in extraordinary ways. ${ }^{30}$

Importantly for environmental rights, the Philippine Rules provide for consideration of cases brought on behalf of nature, known as the "writ of Kalikasan." Such a writ can be pursued on behalf "of persons whose constitutional right to a balanced and healthful ecology is violated, or threatened" by a public official or private entity, "involving environmental damage of such magnitude as to prejudice the life, health or property of inhabitants in two or more cities or provinces." 31

Provisions making environmental information available, as well as requirements relating to standing, proof of injury, and the allocation of fees and costs can also promote or deter invocation of constitutional environmental rights provisions. These issues can be defined constitutionally or statutorily, and can be articulated

29 Pedro Flores y Otros v. Corporacion Del Cobre, Codelco, Division Salvador. Rol. 12.753 FS. 641 (Supreme Court of Chile, 1988).

30 For a discussion of the potential for environmental courts, including in thwarting strategic lawsuits against public participation ("SLAPP" suits), see Rock Pring, [Cite]

31 (Rule 7, s. 1). 
explicitly and exclusively for the enforcement of constitutional rights or without any explicit reference to environmental rights at all. Here too, the more work is done by the text, the less need for judicial interpretation and interpolation. All of this assumes what is perhaps the most significant determinant of the efficacy of constitutional environmental provisions: that they exist within a legal and political framework in which an independent and adequately funded judiciary has the authority, legitimacy, and expertise necessary to meaningfully implement not only environmental rights, but other constitutional guarantees as well. Constitutions in countries where rule of law can be assumed to be entrenched and respected are unlikely to be effectively implemented steadily over time. And environmental rights in particular require persistent application in order for the benefits to be realized.

\section{LIBERALIZE ACCESS TO THE JUDICIAL VINDICATION BY PERMITTING OPEN STANDING, SPECIAL PROCEDURAL RULES AND FEE-SHIFTING} FOR PIL

Before a court reaches the merits of a constitutional claim, it will often consider the preliminary question of standing: whether the party that brought the suit has the right to invoke the court's jurisdiction. Most constitutional traditions have a standing doctrine, although they vary widely from country to country. Some constitutional systems limit who can challenge government action to certain members of the government, or to an ombudsman, while others encourage anyone to seek judicial protection. Although sometimes seen as a fringe question, standing rules can have a dramatic effect on a nation's legal culture: where standing rules are broad and inviting, more people are encouraged to bring more cases to enforce more laws, not only for their own private benefit but for the public good. Conversely, where courts restrict access to judicial fora, compliance with existing laws, as well as the progressive realization of constitutional promises, may be seen more as a matter of political discretion than of constitutional obligation.

Environmental cases, in particular, challenge conventional standing practices. Even where constitutional review is open to members of the public, standing 
has traditionally been limited to those who can assert well-recognized claims, including claims for harms recognized by common law (such as violations of property rights) or interests specifically identified in statutory provisions. In either case, the claims are personal, and standing rules tend to reflect the principle that only individuals who are personally and particularly injured may assert their interests against defendants and lay claim to scarce judicial resources.

Environmental harms, however, tend to affect groups of people generally and similarly. They may affect a whole community or culture or, in the case of climate change, all of humanity. Even where an individual can claim a particular harm for example, where a toxic leak proves carcinogenic - it is most likely that the plaintiff will not be the only person affected; a whole community may be affected by a greater incidence of cancer; indeed, the plaintiff is more likely to be able to show causation in cases where the defendant's wrongful actions have caused widespread, rather than just personal injury. In even more difficult cases, the claim is based on the health not of an individual but of the environment in the abstract, and may raise questions about environmental aesthetics or the health of a particular animal population that do not directly affect most people at all.

Consequently, the good practice is to relax or defray standing requirements to vindicate constitutional environmental rights. Some constitutions make the decision for the court, clearly delineating who may sue and who may not, either for all claims or specifically in environmental cases. In Spain, constitutional environmental rights are protected, but they are enforceable only when an ombudsman initiates litigation. This contrasts markedly with the rest of the Spanishspeaking world, which tends to be receptive to constitutional environmental claims. The constitutions of Argentina and Ecuador, for instance, invite any citizen to vindicate such rights, the latter even allowing claims on behalf of nature itself. ${ }^{32}$ The Constitution of South Africa, too, adopts an open attitude toward standing, which is buttressed by legislation that reinforces the right of any person to approach the court to assert his or her own interest, the interest of another, or the public interest. The statutory authority to sue extends to suits on behalf of

32 Arg. Const. pt. I, ch. II, art. 41-43; Constitución Política de la República del Ecuador. title II, ch. seven, art. 71-74. 
the environment. ${ }^{33}$

In Latin America, constitutional and statutory provisions have encouraged courts to expand standing for environmental cases even to those who cannot show a direct and individual injury; in India and its neighbors, courts have had to infer broad standing from legal and cultural norms. But in both of these regions, as well as in some other countries around the world, the commitment to opening the courthouse doors to environmental claimants is well-established.

Even where the positive law is not as clear, some courts have opened their doors to environmental activists, often seeing these non-traditional stakeholders not only as litigants, but as partners in an ongoing campaign in which the courts are equally invested.

\section{DEVELOP JURISPRUDENCE IN ENVIRONMENTAL CONSTITUTIONALISM}

The final good practice delineated here is to develop the jurisprudence of environmental constitutionalism. Courts asked to apply constitutional environmental rights provisions face numerous difficult choices and have significant discretion in terms of interpretation, vindication, and remediation. There are no generally accepted standards for identifying or vindicating these interests as rights, partly because, in straddling every familiar category of rights, environmental constitutionalism defies easy classification: ${ }^{34}$

Environmental rights partake of human rights as well as non-human rights, protecting such values as biodiversity and nature itself. As a human right, the

33 See PLESSIS, Louis J. Kotze; Anél du. 'Some Brief Observations on Fifteen Years of Environmental Rights Jurisprudence in South Africa.' Journal of Court Innovations. v. 3, 2010, p. 157, 163-164. (discussing South Africa Const. art. 20 and the National Environmental Management Act 107 of 1998 (NEMA), art. 32).

34 See HAYWARD, Tim. Constitutional Environmental Rights, 25-58. Oxford University Press, 2005. (making a case for a human right to an "adequate environment"); HILL, Barry E.; WOLFSON, Steve; TARG, Nicholas. "Human Rights and the Environment: A Synopsis and Some Predications." Geo. Int'I Envtl. L. Rev. v. 16, 2004, p. 361 "[W] hile there appears to be a growing trend favoring a human right to a clean and healthy environment-involving the balancing of social, economic, health, and environmental factors-international bodies, nations, and states have yet to articulate a sufficiently clear legal test or framework so as to ensure consistent, protective application and enforcement of such a right." 
environment can be protected through civil and political rights of participation and access to information, but it can also be protected as a social, economic, and even cultural right. Environmental rights can be collective or individual, and they can apply to the majority or to a discrete, insular, and politically powerless minority. They can be treated as immediately enforceable, or realized progressively over time, according to a legislative plan and limited by the availability of fiscal resources. They can be implicit or explicit, procedural or substantive, and they can be amenable to judicial review or immune to it. They can be positive or negative or both (sometimes in the same case). They can be remedied injunctively or through compensation or declaration, for violations occurring in the past, as well as for harms as yet unknown and to people as yet unborn. In some ways, remedying environmental harms is long overdue, and yet, the primary beneficiaries of environmental rights are future generations. Environmental rights define the relationship between people and the world we live in, though invariably in broad and amorphous terms, without clear foci or boundaries.

So how do courts give content to the concept of environmental rights without allowing them to swallow up every other right? One approach, which borrows from the discourse at the international level, is to limit the reach of environmental rights to already accepted human rights. ${ }^{35}$ Environmental constitutionalism has pushed the conventional limits of this approach in two directions. Even where constitutions do not specifically enumerate particular rights, courts have expanded the scope of interests that constitute violations of familiar human rights by recognizing, for instance, that environmental degradation can constitute a violation of privacy and family life, or that esthetic and recreational environmental interests are essential to enjoying a dignified existence.

35 Abate, supra note 27, at 10 ("Existing sources of domestic and international law embrace a human-centered approach to environmental protection and recognize the connection between human rights and environmental protection. These mechanisms can serve as a viable foundation upon which to build a new system to recognize and protect international environmental human rights."); Onzivu, supra note 39, at 667 ("An emerging right to a healthy environment favors the protection of public health. This is because such a right is viewed as anthropocentric and ecocentric, supporting environmental protection for both public health and intrinsic or aesthetic reasons."). 
A slightly less anthropocentric option is to explicitly recognize environmental rights as a human right, so that environmental harms do not have to fit neatly into the other human rights boxes. ${ }^{36}$ This view reflects an international environmental law approach, and has been incorporated into constitutions throughout the world. This also ensures that environmental values are given at least as much weight as other constitutional values, and perhaps more than some ${ }^{37}$ and more than nonconstitutional values such as development or some property interests.

An even less anthropocentric approach involves a class of rights somewhere between human rights and rights of nature that permit humans to commence constitutional environmental claims to protect nature or wildlife. A final approach would entirely reject anthropocentrism and recognize instead the rights of nature.

There is no "best" practice here; the beauty of constitutionalism is that it takes a global problem and allows each nation to define for itself the particular balance of competing values that will produce the greatest benefit for each particular society. One country may be most concerned with protecting biodiversity, while the principal focus may be to ensure adequate water resources for everyone, while a third may be most concerned with promoting participatory environmental decision-making. Environmental constitutionalism permits each country to address its own priorities. The "good practice" here is that each country's constitutional environmental framework should reflect those priorities in a robust and enduring way.

However, good practices require that as many aspects of litigation be made express and comprehensive in advance as possible, particularly where environmental rights confound ordinary expectations and assumptions generally applicable outside of environmental constitutionalism. For instance, while the beneficiaries of other constitutional rights are the putative litigants - think, for

36 SHELTON, Dinah. "Human Rights and the Environment: What Specific Environmental Rights Have Been Recognized?" Denv. J. Int'I L. \& Pol'y. v. 35, 2006, p. 129, 163 [hereinafter Shelton II] ("Moreover, recognizing a right to environment could encompass elements of nature protection and ecological balance, substantive areas not generally protected under human rights law because of its anthropocentric focus."); Bruckerhoff, supra note 70, at 646 ("A less anthropocentric interpretation of constitutional environmental rights could be one, albeit small, component of national and international efforts to protect the wonders of nature for us and for the benefit of our children.").

37 See Wheeler case noting that environmental rights should prevail over other constitutional rights. 
instance, of those who would claim the right to free speech, or to protection of property - the putative beneficiaries of environmental constitutionalism are often not clear. For example, under a directive principle of state policy, the Indian Constitution requires that the state "endeavour to protect and improve the environment and to safeguard the forests and wild life of the country." ${ }^{38}$ This protection seems to be as much for the benefit of the citizens as for the wildlife and even the forests themselves. But if the wildlife is not safeguarded, who can sue? This is not only a question of standing, but of the nature of the right and purpose of judicial intervention into the policy-making authority of the state. Is the court empowered to protect the flora and fauna, or only to protect the people of the nation? Is a government constitutionally obliged to legislate for the benefit of the rivers, or may it limit its portfolio to helping the citizens directly? Can a constitution protect non-human interests?

These difficult questions of public policy may, in some instances, even require recalibrating the boundaries between the public and private spheres. While some governments are held responsible for the environmental degradation caused by their licensees, some corporations are required to bear the burden of actions for the public good, such as environmental clean-up. In fact, environmental litigation can often reverse normal expectations relating to the roles of public and private parties. Whereas traditional constitutional rights litigation pits the private individual against the public authority, environmental litigation often pits members of the public against a private entity (thus invoking the principle of the horizontal application of constitutional rights and obligations). Moreover, in many of these cases, private individuals are asserting public rights, whereas the government is facilitating private gain. ${ }^{39}$ This does not only mean that the courts should consider standing questions expansively; rather, environmental litigation is increasingly forcing courts to adjust long-held views on the proper allocation of public and private powers. It is therefore good practice to explicitly clarify the putative beneficiary of the right, whether in the constitution itself or in early decisions from the interpreting court.

38 India Const. art. 48A. 1976. Forty-second Amendment.

39 See, e.g., id.; Minors Oposa, supra note 1, at 173 (involving government-issued timber licenses); Kravchenko \& Bonine, supra note 5, at 79 (referring to Hungary helping to sell off forests to private interests). 
Indeed, it seems evident that no constitution will address every issue, or even every major issue, that is likely to arise. Interpreting courts, therefore, have a significant and ongoing responsibility to decide these important questions and to use their opinions to explicate them; this would typically include not only explaining the interpretive choices, but setting out the constitutional values and principles that underlie the decision.

\section{INSTALL COMPLIMENTARY NATIONAL AND SUBNATIONAL ENVIRONMENTAL CONSTITUTIONALISM}

Complimentary national and subnational constitutional enactments are another good practice in environmental constitutionalism. Led by states in the Americas in general, and Brazil in particular, subnational governments around the world have seen fit to constitutionalize substantive and procedural environmental rights, environmental duties, and sustainable development for present and future generations, often with much more specificity and enforceability than is provided in the national constitutions.

Subnational environmental constitutionalism can complement national efforts in several ways. First, subnational constitutions can reflect local environmental concerns that can be ignored or underserved by the national constitution, even when those concerns may address global challenges. Second, subnational constitutions can fill gaps often left open in national constitutions. Remarkable examples of this are found in Brazil, whose state constitutions delineate extensive governmental functions in the service of substantive environmental rights, including promoting biodiversity and sustainability, protecting species and water quality, advancing conservation and environmental education, and enforcing environmental requirements. This type of complementarity reinforces the tenet that environmental protection is a shared obligation between the central and peripheral governments, and is relevant to both the national identity and local control. Germany provides another example of rich state constitutional environmental protection that supports federal environmental constitutionalism. On the other hand, whatever environmental constitutionalism 
exists in the United States is more developed at the state level than at the federal level.

\section{BUNDLE WITH CONSTITUTIONAL RECOGNITION OF RIGHTS TO INFORMATION, PARTICIPATION AND ACCESS TO JUSTICE}

Constitutional provisions that protect procedural rights, particularly including rights to information on environmental matters, rights to participate in environmental decision making, and access to environmental justice, can also materially advance the vindication of substantive environmental rights.

The constitutions of about three dozen countries specifically recognize procedural rights in environmental matters, primarily to advance a human right to a quality environment. Such rights to information, participation, and access to justice in environmental matters are a modern constitutional innovation. These sorts of provisions appear to serve both human and environmental interests, and can advance democratic values. ${ }^{40}$

Most of these constitutional procedural environmental rights provisions seem to be designed to help implement substantive environmental rights. For example, Ukraine's constitution from 2004 creates an individual right to an environment that is "safe for life and health" and further provides for damages when the right has been violated. It further provides for the right of access to and dissemination of information about the environment as well as the quality of food and consumer goods. ${ }^{41}$ Where such provisions expressly denote environmental concerns, they are more likely to be invoked by litigants and recognized by courts in environmental

40 See ONZIVU, William. 'International Environmental Law, The Public's Health, and Domestic Environmental Governance in Developing Countries.' Am. U. Int'l. L. Rev. v. 21, 2006, p. 672 ('International human rights law and national constitutions provide for procedural rights that are instrumental in the protection of human health and the environment. These rights include freedom of association, freedom of information, public participation in decision making processes, and access to justice and judicial review.'); Cramer, supra note 31 , at 74 ('The push for a fundamental human right to environmental protection is in turn inspiring demands for access to government documents and meetings that deal with environmental matters.'); BANDI, Gyula. 'The Right to Environment in Theory and Practice: The Hungarian Experience.' Conn. J. Int'l. L. v. 8, 1993, p. 450-65 (discussing the Hungarian Constitution's public participation provisions); Hayward, supra note 3, at 200-03 (discussing procedural environmental rights in Africa and elsewhere).

41 Ukraine Const. (2004), Ch. II, Art. 50. 
cases, partly because the language itself suggests that they are designed to complement substantive environmental rights. But they can still be indispensable to the vindication of constitutional environmental right, even where they are of general applicability.

\section{ROBINSON TOWNSHIP V. COMMONWEALTH OF PENNSYLVANIA: GOOD PRACTICES IN PRACTICE}

The Robinson Township opinion from the Pennsylvania Supreme Court reflects good practices in constitutional environmental opinion-writing at the juncture of sustainability, governance and sustainability.

In Robinson Township, the Pennsylvania Supreme Court gave life to the state's constitutional environmental rights provision which had been adopted more than 30 years previously. It struck as unconstitutional major parts of "Act 13" a state oil and gas law designed to promote "horizontal hydraulic fracturing," or "hydrofracking." The Environmental Rights Amendment affords rights and imposes public trust duties that are commensurate with other constitutional prerogatives: "It is not a historical accident that the Pennsylvania Constitution now places citizens' environmental rights on par with their political rights." 42 Act 27 was enacted based on "the mischief to be remedied and the object to be attained," namely, to address environmental degradation in the state by promoting individual environmental rights and requiring governmental authorities to hold natural resources in public trust. ${ }^{43}$ Horizontal hydrofracking, on the other hand, is a relatively new engineering technique that can be used to gain access to the natural oil and gas embedded in deep shale "plays" a mile or more under the surface of the earth. The Pennsylvania legislature enacted Act 13 in 2012 to promote the development of the state's extensive "Marcellus Shale" play.

42 Robinson Township et al. v. Commonwealth of Pennsylvania, Pa. Sup. Ct., No. J-127A-D2012 (decided Dec. 19, 2013) (plurality opinion), available at: http://blogs.law.widener. edu/envirolawcenter/files/2013/12/J-127A-D-2012oajc1.pdf.

43 Robinson Township et al. v. Commonwealth of Pennsylvania, Pa. Sup. Ct., No. J-127A-D2012 (decided Dec. 19, 2013) (plurality opinion), available at: http://blogs.law.widener. edu/envirolawcenter/files/2013/12/J-127A-D-2012oajc1.pdf. 
A plurality of the court determined that Act 13 contravenes the recommendation, in Section 27, that the state hold natural resources "in the public trust": "we agree with the citizens that as an exercise of the police power, [Act 13 is] incompatible with the Commonwealth's duty as trustee of Pennsylvania's public natural resources." It observed: "As the citizens illustrate, development of the natural gas industry in the Commonwealth unquestionably has and will have a lasting, and undeniably detrimental, impact on the quality ... of Pennsylvania's environment, which are part of the public trust." ${ }^{44}$

The opinion of the plurality in Robinson Township reinforces environmental constitutionalism insofar as it represents an authentic attempt to engage the text of the Environmental Rights Amendment. First, it noted that Article 27 - much like many provisions that provide such rights - vests two rights in the people of the state. The first is a right to clean air, pure water, and to the preservation of the natural, scenic, historic and esthetic values of the environment. The second is "a limitation on the state's power to act contrary to this right." Importantly, it held that these rights are equal in status and enforceability to any other rights included in the state constitution, including property rights.

Secondly, it enforces the "public trust" provisions, that is, the obligations of the state to hold resources in the public trust for all people. Because the state is the trustee of these resources, it has a fiduciary duty to "conserve and maintain" them: "The plain meaning of the terms conserve and maintain implicates a duty to prevent and remedy the degradation, diminution, or depletion of our public natural resources."

The plurality in Robinson Township also noted that the Environmental Rights Amendment serves both present and future generations. Echoing sentiments from the majority opinion in Minors Oposa, it observed: "By any responsible account, the exploitation of the Marcellus Shale Formation will produce a detrimental effect on the environment, on the people, their children, and future generations, and potentially on the public purse, perhaps rivaling the environmental effects of

44 Robinson Township et al. v. Commonwealth of Pennsylvania, Pa. Sup. Ct., No. J-127A-D2012 (decided Dec. 19, 2013) (plurality opinion), available at: http://blogs.law.widener. edu/envirolawcenter/files/2013/12/J-127A-D-2012oajc1.pdf. 
coal extraction." In so doing, the opinion of the plurality advances, in particular, the purpose of constitutional-enshrinement of environmental rights and public trust duties in the first place - to promote environmental protection and advance individual rights to a quality environment.

In some ways, Robinson Township is a more modern embodiment of good practices in environmental jurisprudence reflected in the in Minors Oposa, in which the Philippine Supreme Court laid the foundation for recognizing the rights of future generations to bring environmental claims:

Petitioners [who are] minors assert that they represent their generation as well as generations yet unborn. We find no difficulty in ruling that they can, for themselves, for others of their generation and for the succeeding generations, file a class suit. Their personality to sue in behalf of the succeeding generations can only be based on the concept of intergenerational responsibility insofar as the right to a balanced and healthful ecology is concerned.

But the court went further and elucidated the meaning of the constitutional mandate to protect the rhythm and harmony of nature.

Nature means the created world in its entirety. Such rhythm and harmony indispensably include, inter alia, the judicious disposition, utilization, management, renewal and conservation of the country's forest, mineral, land, waters, fisheries, wildlife, off-shore areas and other natural resources to the end that their exploration, development and utilization be equitably accessible to the present as well as future generations.

With this expansive and fundamental conception of nature, the court was able to justify its holding that children and future generations had a legitimate and cognizable legal claim.

Needless to say, every generation has a responsibility to the next to preserve that rhythm and harmony for the full enjoyment of a balanced and healthful ecology. Put a little differently, the minors' assertion of their right to a sound environment constitutes, at the same time, the performance of their obligation to ensure the protection of that right for the generations to come. ${ }^{45}$

45 Minors Oposa, text at nn. 9-10. 
Robinson Township clearly reflects the good practices outlined in the prior section. The underlying provisions were adopted in a governance structure that already recognized social, economic and cultural rights. The underlying rights were explicit and self-enforcing, and were placed within an appropriate constitutional constellation. The rights were also coupled with evolving notions of environmental constitutionalism concerning sustainability, future generations, public trust, and energy use, and afforded participatory rights in a scaffolded legislative and regulatory setting with complimentary municipal and local considerations.

\section{CONCLUSION}

The experience of the courts, in trying to make sense of constitutional environmental rights and give them serious consideration, reveals a lesson which, when learned, may significantly enrich the praxis of constitutional law generally. At heart, the adoption of good practices in the constitutional incorporation of environmental rights, protections, and procedures is multi-faceted, and serves as a proxy for social agreements with present and future generations.

\section{BIBLIOGRAPHIC REFERENCES}

ARGENTINA. Argentina Constitution. 1994.

BANDI, Gyula. 'The Right to Environment in Theory and Practice: The Hungarian Experience.' Conn. J. Int'I. L. v. 8, 1993.

BRUCH, Carl; COKER, Wole; VANARSDALE, Chris. 'Constitutional Environmental Law: Giving Force to Fundamental Principles in Africa.' Colum. J. Envtl. L, v. 26, p. 166-176, 2001.

DALY, Erin. "The Ecuadorian Exemplar: The First Ever Vindications Of Constitutional Rights Of Nature." RECIEL, v. 21, n. 1, 2012. Available at: <http://celdf.live2.radicaldesigns.org/ downloads/The_Ecuadorian_Exemplar_The_First_Ever_Vindications_of_Constitutional_Rights_ of_Nature.pdf $>$.

GELLERS, Joshua. Survival of the Greenest:A Statistical Analysis of Constitutional Environmental Rights, 2012. Available at: <http://papers.ssrn.com/sol3/papers.cfm?abstract_id=2103960>. 
GLOBAL ALLIANCE FOR THE RIGHTS OF NATURE. Turkey calling for ecological constitution. Avaiable at: <http://therightsofnature.org/rights-of-nature-laws/turkey-ecologicalconstitution/>.

Hayward, Tim. Constitutional Environmental Rights, 25-58. Oxford University Press, 2005.

HILL, Barry E.; WOLFSON, Steve; TARG, Nicholas. "Human Rights and the Environment: A Synopsis and Some Predications." Geo. Int'I Envtl. L. Rev. v. 16, 2004.

JUNG, Courtney; ROSEVEAR, Evan. Economic and Social Rights Across Time, Regions, and Legal Traditions: A Preliminary Analysis of the TIESR Dataset. 30 Nordic Jrnl. Hum. Rights, 2012.

MAY, James R. 'Constituting Fundamental Environmental Rights Worldwide.' Pace Envtl. L. Rev. v. 23, p. 113, 2006.

MAY, James R.; DALY, Erin. 'Vindicating Fundamental Environmental Rights Worldwide.' Ore. Rev. Intl. L. v. 11, p. 365-440, 2010.

MAY, James R.; Daly, Erin. 'Constitutional Environmental Rights Worldwide.' In: May, James R. Principles of Constitutional Environmental Law. ABA Publishing, Environmental Law Institute, 2011.

MAY, James R.; DALY, Erin. 'Global Constitutional Environmental Rights.' In: ALAM, Shawkat; BHUIYAN, Jahid Hossain; CHOWDHURY, Tareq M.R.; TECHERA, Erika J. Routledge Handbook of International Environmental Law. Routledge, 2012.

MAY, James R.; DALY, Erin. 'New Directors in Earth Rights, Environmental Rights and Human Rights: Six Facets of Constitutionally Embedded Environmental Rights Worldwide.' IUCN Academy of Environmental Law E-Journal. v. 1, 2011.

ONZIVU, William. 'International Environmental Law, The Public's Health, and Domestic Environmental Governance in Developing Countries.' Am. U. Int'I. L. Rev. v. 21, 2006.

PLESSIS, Louis J. Kotze; Anél du. 'Some Brief Observations on Fifteen Years of Environmental Rights Jurisprudence in South Africa.' Journal of Court Innovations. v. 3, 2010.

SHELTON, Dinah. "Human Rights and the Environment: What Specific Environmental Rights Have Been Recognized?" Denv. J. Int'I L. \& Pol'y. v. 35, 2006.

SRIPATI, Vijayashri. Human Rights in India - Fifty Years after Independence. 26 Denv. J. Int'I L. \& Pol'y, 1997. 
VIDAL, John. Bolivia enshrines natural world's rights with equal status for Mother Earth. Avaiable at: <http://www.guardian.co.uk/environment/2011/apr/10/bolivia-enshrinesnatural-worlds-rights $>$

WHEELER c. Director de la Procuraduria General Del Estado de Loja Juicio, No. 111212011-0010 ('Wheeler'). Available at < http://blogs.law.widener.edu/envirolawblog/2011/07/12/ ecuadorian-courtrecognizes-constitutional-right-to-nature/>.

Recebido em: setembro/2017

Aprovado em: dezembro/2017 